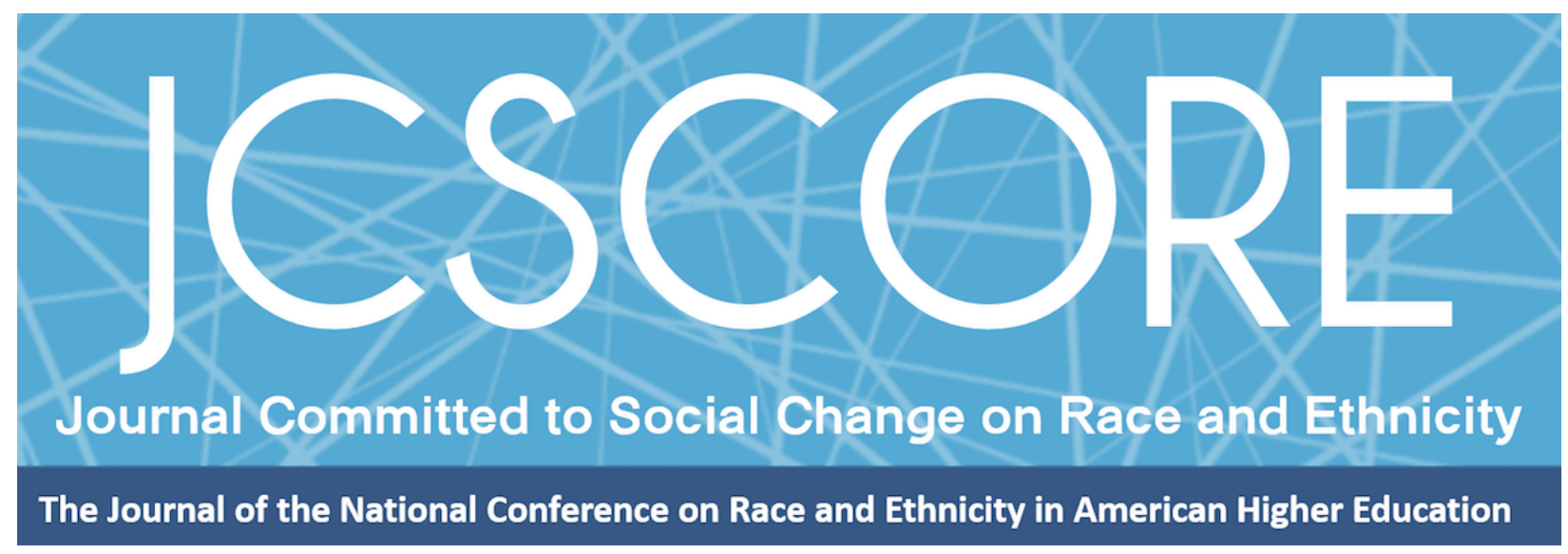

\title{
STUDENTS PERSPECTIVES ON HOLISTIC MENTORING PRACTICES IN STEM FIELDS
}

Courtney L. Luedke

University of Wisconsin - Whitewater

Dorian L. McCoy

University of Tennessee - Knoxville

Rachelle Winkle-Wagner

University of Wisconsin - Madison

Jamila Lee-Johnson

University of Wisconsin - Madison

Journal Committed to Social Change on Race and Ethnicity

Volume 5, Issue 1 | 2019

Copyright ( 2019 Board of Regents of The University of Oklahoma on behalf of the Southwest Center for Human Relations Studies.

Permission of the Publisher is required for resale or distribution and for all derivative works, including compilations and translations. Quoting small sections of text is allowed as long as there is appropriate attribution. 


\title{
Students Perspectives on Holistic Mentoring Practices in STEM Fields
}

\author{
Courtney L. Luedke \\ University of Wisconsin - Whitewater \\ Dorian L. McCoy \\ University of Tennessee - Knoxville \\ Rachelle Winkle-Wagner \\ University of Wisconsin - Madison \\ Jamila Lee-Johnson \\ University of Wisconsin - Madison
}

This critical multi-site case study examined the holistic mentoring practices provided by faculty to Students of Color in STEM fields at a predominantly White institution and a historically Black institution. We employed Bourdieu's social reproduction theory to examine the ways in which social capital developed through faculty-student mentoring relationships led to the accumulation of cultural capital valued in STEM fields and higher education more broadly.

Student-faculty relationships are critical to students' experiences in higher education (Astin, 1984; Azizova, 2016; Cole \& Griffin, 2013; Gipson \& Mitchell, 2017; McCoy, Luedke, \& Winkle-Wagner, 2017; Tinto, 1987/1993). Mentoring is particularly important to Students of Color who are underrepresented in the science, technology, engineering, and mathematics (STEM) fields (Griffin, Pérez, Holmes, \& Mayo, 2010; McCoy et al., 2017; McCoy, Winkle-Wagner, \& Luedke, 2015). There is also a growing body of evidence that asserts the importance of holistic support in mentoring. Holistic mentoring includes supporting students' full lives beyond academics (Crisp, 2010; Luedke, 2017; Patton \& Harper, 2003). Yet, there is limited research that suggests specific practices mentors could use to achieve more positive mentoring with underrepresented students (see, Luedke, 2017; Packard, 2015; Young \& Brooks, 2008). 
Journal Committed to Social Change on Race and Ethnicity | 2019

Mentoring practices could be one campus effort toward inclusion of underrepresented students, amidst many policies and practices that may be perceived as exclusive (Templeton, Love, Davis, \& Davis, 2016). The lack of identification of specific mentoring practices that Students of Color might perceive as beneficial and culturally sensitive is problematic because faculty mentors may have positive intentions, but little understanding of how to actually practice culturally sensitive mentoring (McCoy et al., 2015). Faculty do not typically receive training on approaches to mentoring students. As a result, they often reproduce the mentoring tactics they experienced (Hall \& Burns, 2009), which may perpetuate the racial inequalities present in STEM fields.

The purpose of this study was to explore the mentoring practices that faculty provided Students of Color majoring in STEM fields. Findings revealed that when students were mentored holistically, where mentors took both their academic and emotional lives into account, students described meaningful gains that contributed to their persistence in STEM disciplines and college more generally. The findings of this study are important not only because they reaffirm the importance of mentoring Students of Color in ways that honor their backgrounds, but also because this is one of the first studies to demonstrate specific strategies that faculty mentors employ with their students. Faculty and staff who work with Students of Color could use these findings as exemplar practices to apply in their mentoring practices.

\section{Review of Literature}

Mentoring has been defined in numerous ways, including disciplinary activities, support and advice (Tillman, 2001), actions conducted for a mentee by a mentor (Crisp \& Cruz, 2009), and a process of socialization (Davidson \& Foster-Johnson, 2001; 
Journal Committed to Social Change on Race and Ethnicity | 2019

Tillman, 2001). Johnson and Huwe (2003) defined mentoring as a relationship in which the mentor provides the protégé "with knowledge, advice, challenge, counsel, and support in the [protégés] pursuit of becoming a full member of a particular profession" (p. 6). Whereas Parks-Saltzman, Wada, and Mogami (2012) described the mentor/protégé relationship as one in which a more experienced individual engages in numerous roles to facilitate the professional development of a less experienced person. Mentoring can occur in both formal (e.g., meeting with an academic advisor to discuss coursework) and informal (e.g., lunch with a professor) ways. Numerous scholars contend that informal mentoring may be more effective and result in greater outcomes for Students of Color (Davidson \& Foster-Johnson, 2001; Gandara, 1999; Luedke, 2017). This is particularly important to reflect upon as one considers the inherent power imbalance between faculty and students, particularly within formalized mentorprotégé relationships (Azizova \& Felder, 2017; Hall \& Burns, 2009). The imbalanced power dynamics in student-faculty relationships may be exacerbated within PWls (Azizova \& Felder, 2017) and within the STEM disciplines, where science is perceived to be "objective, apolitical and meritocratic" (Baber, 2015, p. 261).

Faculty mentoring of students is particularly important in the STEM disciplines because so much of student socialization is related to working closely with faculty in laboratories (Gasman, Nguyen, Conrad, Lundberg, \& Commodore, 2017; Griffin et al., 2010; Palmer, Maramba, \& Dancy, 2011). Administrators of diversity programs in STEM noted that faculty are often unwilling to collaborate and engage in diversity programming unless interest-convergence is present, where the faculty members identify a personal benefit to their participation (Baber, 2015). Students of Color in 
Journal Committed to Social Change on Race and Ethnicity | 2019

STEM disciplines may face additional barriers in developing an identity as a scientist compared to their White peers because they are often working with a mostly White and male science faculty community (Carlone \& Johnson, 2007; McGee, 2016; McGee \& Martin, 2011). For example, McGee and Martin's (2011) interviews with Students of Color in mathematics and engineering suggested that these students had to constantly manage stereotypes about their intellectual abilities during their degree programs. Faculty mentors can either help to disrupt these stereotypes, or they can activate them. Carlone and Johnson (2007) found some Women of Color in STEM disciplines held altruistic values that propelled their persistence in STEM, while some Women of Color relied on external support from their family or community to persist, particularly in the absence of validation of their academic abilities by science faculty.

Tsui's (2007) review of the literature on strategies to diversify STEM disciplines found Students of Color with positive mentoring experienced lower attrition rates, higher GPAs, increased self-efficacy, and better-defined academic goals (see also, McKinney de Royston, Vakil, Nasir, Ross, Givens, \& Holman, 2017). Students who experienced positive mentoring relationships with faculty (and also postdoctoral scholars and graduate students) reported greater gains in STEM research skills (Ghee, Keels, NealSpence, \& Baker, 2016). Scholarship also suggests that building a positive relationship with a mentor in the STEM disciplines may contribute to students' ability to see themselves as scientists (Gasman et al., 2017; James \& Carlson, 2012). Developing an identity as a scientist starts early in an educational career (Pinkard, Erete, Martin, \& McKinney de Royston, 2017) and can contribute to an individual's long-term persistence in a STEM field (Rodriguez \& Lehman, 2018). Students benefit greatly from 
Journal Committed to Social Change on Race and Ethnicity | 2019

individualized mentoring relationships: relationships where mentors get to know students personally, invest time in their relationships, and demonstrate their interest and care in students (Gasman et al., 2017; Griffin et al., 2010; Luedke, 2017; Schreiner, Noel, Anderson, \& Cantwell, 2011).

\section{Holistic Mentoring}

Many undergraduate students do not receive the academic and social support that is essential to their overall success as students (Nora \& Crisp, 2007; Ward, Thomas, \& Disch, 2014). On many college and university campuses, historically underrepresented students (i.e. Students of Color, first-generation, low socio-economic status) are in environments where they experience isolation, uncertainty, and marginalization (Abrica, 2015; Torrens, Salinas, \& Floyd, 2017; Ward et al., 2014).

Thus, mentoring is critical for those students who are inexperienced, or lack the cultural capital valued in their academic discipline and the broader field of higher education.

Furthermore, mentoring can assist students with navigating challenges and opportunities that are unfamiliar to them (Heppner, 2017; Luedke, 2017; McCoy et al., 2017; Torrens et al., 2017; Ward et al., 2014).

Nora and Crisp (2007) determined that mentoring programs are most successful when they: assist students in their transition to higher education, encourage participation in the classroom, and promote co-curricular involvement. Holistic mentoring can be defined by a mentoring relationship where the mentor considers the full student, their background, their lives outside of college and their role as a student, during the mentoring process (Luedke, 2017). Nora and Crisp's (2007) conceptual framework of holistic mentoring includes psychological/emotional support, degree and 
career support, academic subject knowledge support, and acknowledgement of a role model. Psychosocial and emotional support includes encouragement, understanding, and active empathetic listening (Crisp, Baker, Griffin, Lunsford, \& Pifer, 2017; Nora \& Crisp, 2007). Degree and career support provided by a mentor centers on assessment of a student's potential and abilities. Academic and career mentoring also involves establishing long-term goals and strategies for achieving those goals (Crisp et al, 2017; Nora \& Crisp, 2007). Knowledge support for academic subjects seeks to enhance students' skill development in a particular area of study, such as mathematics (Crisp et al, 2017; Nora \& Crisp, 2007). The final component, role modeling, includes both having access to a mentor and learning from the mentors' successes and failures (Crisp et al, 2017; Nora \& Crisp, 2007).

While there is a clear body of evidence suggesting the crucial importance of faculty mentoring for Students of Color in STEM disciplines, there remains a gap in understanding of the specific practices that might either facilitate positive mentoring or hinder it. For example, while some research suggests the importance of being racially conscious in mentoring (Luedke, 2017; McCoy et al., 2015; McCoy et al., 2017), there remains limited information on the practices that will allow for that racial consciousness. Packard's (2015) review of the literature on successful mentoring strategies for STEM disciplines is one example of such efforts. However, more student-driven, studentvoiced data offering perspectives on the mentoring practices that Students of Color perceive as positive is still needed.

\section{Theoretical Framework}


Journal Committed to Social Change on Race and Ethnicity | 2019

This study is grounded in Bourdieu's (1979/1984) social reproduction theory, which examines how inequality is transferred or transformed over time. Specifically, the full study is grounded in Bourdieu's concepts of field (social setting such as a college campus), cultural capital (knowledge, skills, abilities that are rewarded in particular settings), social capital (relationships and obligations that are rewarded in particular settings) and habitus (a dynamic and fluid set of dispositions and/or tastes that structure what opportunities seem viable). Habitus can structure the actions that seem viable for an individual to take. In this particular analysis, we were interested in uncovering a better understanding of how social capital might influence the types of cultural capital that Students of Color are able to acquire while they are in STEM disciplines from their faculty mentoring relationships. Ultimately, the social and cultural capital could transform the habitus or the sets of actions one might take. Our theoretical framework served as a foundation for the questions that we asked in the study and for the way we crafted our data analysis. Below we describe how we specifically used and defined social and cultural capital in this particular analysis.

Social capital in this study was represented by students' descriptions of relationships with faculty members who would connect the student to their academic discipline in STEM areas. In other words, for the relationship to be a source of social capital that could be activated, the relationship would need to relate to a students' academic discipline and be able to be used as an asset in that discipline. However, for social capital to be successful (i.e., valuable to the student and the faculty member), the relationship must also honor students holistically. We define cultural capital as connected to skills, knowledge, or abilities that are rewarded in STEM disciplines and 
Journal Committed to Social Change on Race and Ethnicity | 2019

the skills, knowledge, or capacities that students might bring with them from their backgrounds. We were interested in both the new skills and knowledge that students might acquire as part of their academic discipline alongside background skills and knowledge. We recognize that students' habitus is malleable and may shift over time as students develop and acquire additional capital during their college degree (or in their STEM degree program). Our use of cultural capital as both something that is acquired in education and through one's background (family, neighborhood) is consistent with Bourdieu's (1979/1984) initial conception.

\section{Methods and Data Sources}

Because of the study's exploratory nature, we employed a critical multisite case study approach (Bartlett \& Vavrus, 2016; Flyvbjerg, 2007; Merriam \& Tisdale, 2016). Similar to previous case study research (Bartlett \& Vavrus, 2016; Flyvbjerg 2007), we focused on the participants' perspectives, rather than on an assessment of the disciplines' effectiveness or structures. Consistent with many case study methodologies, our study was bounded by location (two institutions in the same midAtlantic state) and time (data collected within a set period of time, one academic year). The research question guiding our study was: What are Students' of Color perceptions of holistic faculty mentoring practices?

We examined Students' of Color holistic mentoring experiences with faculty at two, public, land-grant institutions in a mid-Atlantic state. The two institutions included Mid-Atlantic University (MAU), a large, predominantly White institution (PWI) that is the state's flagship institution; and Mid-Atlantic State University (MASU), the state's historically Black land-grant institution. Mid-Atlantic University has approximately 
22,000 students enrolled. The racial demographics of the tenure-line faculty at MAU include: $81 \%$ White, 12\% Asian/Pacific Islander, 4\% Black, 2\% Latina/o/ $x^{1}$, and $<1 \%$ Native American (MAU Institutional Data). Mid-Atlantic State University has approximately 3,800 students enrolled. The racial demographics of the tenure-line faculty at MASU include: $38 \%$ White, $35 \%$ Black, 21\% Asian/Pacific Islander, $2 \%$ Native American, $1 \%$ Latina/o/x, and 3\% who identified as other (MASU Institutional data).

To identify and select participants, we used purposeful sampling (Bartlett \& Vavrus, 2016; Carspecken, 1996; Merriam \& Tisdale, 2016). More specifically, we used criterion sampling. Each participant identified as a Student of Color enrolled in science, technology, engineering, and mathematics (STEM) disciplines at two land-grant institutions within the same mid-Atlantic state. Thirty-one undergraduate students participated in the study - 21 MAU students and 10 MASU students. See Table 1 for additional participant demographic information.

This study was IRB approved and data were collected via semi-structured interviews, documents, and institutional websites (Merriam \& Tisdale, 2016). However, we focused specifically on the data from the semi-structured interviews for this analysis. All interviews lasted approximately 60-75 minutes in a location of the participant's choosing. Participants were interviewed by professional staff of the MAU Research and Development Center. We collaborated with the Research and Development Center to train the interviewers on the interview protocol and approach to the study. A

\footnotetext{
${ }^{1}$ Researchers who study participants with origins in Latin America use the terms Latino, Latina, Latin@ to describe people from these populations. However, these terms imply a gender binary. Recently, scholars have examined the evolution of the term Latinx, which seeks to move beyond the gender binary (Salinas \& Lozano, 2017). Salinas and Lozano (2017) advocate for using the terms that people use to identify themselves and we agree with this stance. We use Latina/o/x here to include those who identify within and across the binary. Participants in our study identified as Latina and Latino.
} 
professional transcriber transcribed each interview. Participants selected their own pseudonyms and we assigned pseudonyms to the institutions, and any other names mentioned during the interview, to protect the participants' anonymity.

Table 1. Sample Demographic Information

\begin{tabular}{|c|c|c|c|c|}
\hline $\begin{array}{l}\text { Pseudonym/ } \\
\text { Gender }^{2}\end{array}$ & Major & $\begin{array}{l}\text { Class } \\
\text { Standing }^{3}\end{array}$ & Race/Ethnicity & $\begin{array}{l}\text { First- } \\
\text { Generation }\end{array}$ \\
\hline \multicolumn{5}{|c|}{ Mid-Atlantic University_Predominantly White University } \\
\hline Michelle (F) & $\begin{array}{l}\text { Biological } \\
\text { Sciences }\end{array}$ & F S J S & African American & No \\
\hline Hermes (M) & Engineering & $\mathrm{F} S \mathrm{JS}$ & Black, & Yes \\
\hline Dave (M) & Engineering & $F \vec{S} \mathrm{~S}$ & African American & Yes \\
\hline $\operatorname{lnez}(\mathrm{F})$ & Health Sciences & $F S J S^{*}$ & African American & No \\
\hline Kristen (F) & $\begin{array}{l}\text { Environmental } \\
\text { Sciences }\end{array}$ & $\mathrm{F} \mathrm{S} \mathrm{J} \mathrm{S*}$ & Black & No \\
\hline Frank (M) & Engineering & $\mathrm{F} S \mathrm{JS}$ & Black/African & No \\
\hline Mike (M) & Engineering & $\mathrm{F} S \mathrm{JS}$ & Haitian/Black & Yes \\
\hline Ashley (F) & $\begin{array}{l}\text { Physics/ } \\
\text { Engineering }\end{array}$ & FS J S & Black & No \\
\hline James (M) & Engineering & F S J S & Puerto Rican & No \\
\hline Michelle $(F)$ & Nursing & $F S J S$ & African American & No \\
\hline Lesa $(F)$ & $\begin{array}{l}\text { Medical } \\
\text { Technology }\end{array}$ & $F \bar{S} \mathrm{JS}$ & African/Black & Yes \\
\hline Luis (M) & $\begin{array}{l}\text { Health Sciences/ } \\
\text { Biology }\end{array}$ & $\mathrm{FS} J \mathrm{~S}$ & Latino & Yes \\
\hline Janay (F) & Engineering & $\mathrm{F} S \mathrm{JS}$ & African American & No \\
\hline Shawn (M) & Engineering & $F S J S$ & African American & No \\
\hline Carl (M) & Engineering & $F S \sqrt{S}$ & African American & No \\
\hline Rachel (F) & Dietetics & $\mathrm{FSJ}$ & Latina & Yes \\
\hline Antonio (M) & Biology & $F S \mathrm{~J}$ & Latino & No \\
\hline Juan (M) & Biology & $\mathrm{FS} \mathrm{JS}$ & Hispanic & Yes \\
\hline Dice $(F)$ & Nursing & F S J S & African American & Yes \\
\hline Sue $(F)$ & Exercise Science & $F S J S$ & African American & No \\
\hline Kevin (M) & Exercise Science & F S J S & $\begin{array}{l}\text { African American/ } \\
\text { Native American }\end{array}$ & Yes \\
\hline \multicolumn{5}{|c|}{ Mid-Atlantic State University_Historically Black College/University } \\
\hline AJ (M) & $\begin{array}{l}\text { Wildlife } \\
\text { Management }\end{array}$ & F S J S & $\begin{array}{l}\text { African American, } \\
\text { Irish, Comanche, } \\
\text { Guyanese }\end{array}$ & No \\
\hline Steven (M) & Engineering & $\mathrm{FSJS}$ & Black & No \\
\hline Ted (M) & Biology & $\mathrm{FS} S$ & African American & Yes \\
\hline Fellisha $(F)$ & Biology & $\mathrm{FSJS}$ & Black & \\
\hline Betty $(F)$ & Biology & $\mathrm{FSJ}$ & African American & Yes \\
\hline Grace $(F)$ & Biology & $F S \mathrm{~J}$ & African American & No \\
\hline Latrice $(F)$ & Biology & $F S \unlhd S$ & African American & No \\
\hline
\end{tabular}


Journal Committed to Social Change on Race and Ethnicity | 2019

$\begin{array}{lllll}\text { Vanessa }(F) & \text { Biology } & F S J S & \text { African American } & \text { Yes } \\ \text { Vivian (F) } & \text { Math } & \text { F S J } \frac{S}{S} & \text { African American } & \text { No } \\ \text { Ashton }(M) & \text { Agriculture } & \text { F S J } & \text { Black } & \text { No }\end{array}$

Data analysis proceeded in four stages so that we could develop a deeper

understanding of participants' views on successful mentoring practices. First, we coded all data based on broad categories (e.g., family, choice of major, peer relationships, mentoring, etc.). After categorizing our data in this way, we "pulled out" the data related to student-faculty mentoring. Second, we coded the mentoring data using an "in vivo" coding process where we coded a two-to-five word phrase in the participants' language (Carspecken, 1996). We categorized those codes into a code list and then separated the codes into themes. Third, we used a data reduction technique developed by Neumann (2009) where we asked a question of the data: What does this participant say about student-faculty mentoring? Based on this question, we found that many participants were describing holistic mentoring practices. Finally, we asked a second analytic question (Neumann, 2009) of the mentoring data: How does this participant describe holistic mentoring practices?

To develop rigor and trustworthiness, we engaged in multiple methods of data trustworthiness (Merriam \& Tisdell, 2016). For example, we used a process of triangulation where we used multiple sources of data in the larger study and multiple data analysis techniques to check our interpretations. We also employed member checks where participants reviewed the interview transcripts and we made changes based on their feedback (Carspecken, 1996). Finally, we each analyzed the data individually before coming together to discuss our findings. We engaged in a process of peer debriefing (Merriam \& Tisdell, 2016) where we scheduled conference calls to check and discuss one another's analysis. 


\section{Holistic Mentoring Relationships: Faculty Advisors who Care}

Positive mentoring relationships were often holistic, at times exceeding the common mentoring tasks of academic or career advising. These mentoring relationships came from a deep trust that had been built between the student and the faculty member. At times, holistic mentors demonstrated support for various needs that students had during their degree programs. For example, Betty, an African American, undergraduate biology major at MASU explained:

I really like my advisor... because when we have meetings, he doesn't just [ask about] classes... He will ask about the class and ask me [why] I didn't like the class... He would tell me his opinion about what he thinks I should do.

Betty noted that her advisor, who identified racially as White, did not just help her choose classes, he talked with her about what she liked and did not like about particular courses. Part of what made Betty's relationship with her advisor noteworthy was that he seemed to encourage Betty by telling her she was doing a good job in school. Betty appeared to feel emotionally supported by her advisor, and she felt like her opinions and ideas were valued. Because of feeling like her opinions and ideas were valued, she felt more comfortable asking her advisor for assistance when needed.

Fellisha, a Black, biology major, at MASU, described her experience with her academic advisor in a similar way as Betty. She noted that her advisor did more than just tell her what classes to take:

My advisor [mentors me by] talking about my schedule, my classes. She will try to help me and tell me what direction to take as far as talking to my professors, [and] how I study. She will try to give me some guidelines as far as that goes...I was having some financial issues and she helped me seek out certain scholarships that I could get, decisions I could make, or other routes...other than 
when she in class, she is there, you just knock on her door and she will tell you come in.

Fellisha named a few of the more typical advising techniques (i.e., such as advising about courses); but then she discussed other areas where her advisor had been helpful. Similar to Betty's experience, Fellisha's advisor did more than just advise her on classes; the advisor shared how to acquire financial assistance and how to successfully study in the STEM disciplines.

Vanessa, an African American student, majoring in biology, at MASU described how her White faculty supervisor for her on-campus employment became more of a mentor to her:

She's very clear that [in] our job as a student worker, the student part comes first. And she's always interested in our classes, what we're doing, how things are going, and our interactions with other students. She offers advice, you know, maybe on how to deal with other students, on how to think about the class subjects, like how to break it down so it's not so difficult.

Vanessa shared how this faculty mentor offered advice and engaged in conversations with her about various factors affecting her college experience, such as interactions with peers and dealing with conflict. This faculty mentor also helped Vanessa discuss STEM coursework, making it seem more accessible to Vanessa.

Michelle, an African American, biological sciences major at MAU, recalled her faculty mentor, an African American woman, who she developed a relationship with:

She is not technically [my] academic advisor, ... but because I'm there, I see her everyday... I always wanted [to go to] her first and she was the reason why I even got introduced to [Ivy League University], because I went to a national conference and she paid me to go there to present my research, and through that a graduate school fair. When I was presenting my research on HIV, that I did at the [Prestigious Research One University]. [Ivy League University] was interested. I was in the research [program] from the [Prestigious Research One University]... She's like, "I know this person... who is on the board of directors of this program." I applied and I got in. I definitely owe her a lot. 
Michelle's mentor was not her advisor, but had helped her to create a social network in her discipline. She shared information about opportunities such as summer research and conference opportunities. Michelle credited the social network that was opened by her mentor as helping her to gain admittance into a summer research program. Michelle described how this mentor prepared her to present her research: "she [was] prepping me and guiding me and making sure that l'm ready for my presentation." Michelle also shared how she later joined the same sorority as this woman, and through this strengthened their bond.

Similar to Michelle, Ashton, a Black student, majoring in agriculture at MASU also received support in the graduate school process. Ashton highlighted his research advisor's role, with whom he worked on a summer research internship and his honors thesis:

With this advisor, I used to just check in with her [about] my topic, fieldwork, lab work, and/or presentations or writings and also about graduate school. My research advisor's actually been more-one of the more forefront members and has helped with the grad school applications and grad school.

Ashton received out-of-classroom support in conducting research, an experience valued by graduate school search committees. He also received support and guidance in searching for and applying to graduate programs from his research mentor. All of these experiences provided Ashton with knowledge and skills valued by admissions committees and in graduate school more generally.

Grace, an African American student, majoring in forensic biology at MASU shared how one faculty member of color worked with her to secure a summer research experience after Grace was unable to secure one on her own. 
Dr. Wood at MASU...I know she worked with Ms. Mallard before that. And so, I went to her and I said, 'Look, I need a research [assistantship]. I don't know how you're going to do this but I need a research [experience] this summer.' She was like, you know, it's kind of late, but just fill [out] the form and l'll talk to Ms. Mallard. She sent Ms. Mallard an email and cc'd me; [and] me and Ms. Mallard started talking. And then she was able to get me in touch with Dr. Shelton and it just kept going and going. Finally, I was in!

Grace benefitted from her relationship with a faculty member who assisted her in securing a summer research experience that she needed for graduation (as a component of her curriculum requirements). Grace contacted several faculty members to obtain a place on a research team; however, it was not until Dr. Wood reached out on her behalf that she received this opportunity and experience. An experience vital to her graduation, and beneficial if she chooses to pursue graduate school upon graduation (one of two options she is considering).

Sometimes holistic mentoring also included informal ways to cultivate relationships between faculty and students. When Ted, an African American, biology major at MASU was asked to discuss a person who has really supported him in college he described one of his advisors who is a faculty member. Ted shared one of his favorite memories with this faculty member who is a Person of Color, "we had a little lab party at the end of the semester, we played a couple of games, stuff like that, I thought that was fun." In sharing this experience, Ted shared the personal, non-academic relationship this faculty member had built with their research team. These types of experiences developed a personal and informal relationship between them.

While holistic mentoring sometimes meant going above and beyond some of the typical advising roles, there were times that participants described mentoring as linked to important emotional support during their degree programs. Antonio, a Latino biology 
major at MAU, described the robust support and holistic mentoring provided by his advisor, a faculty member in biology:

Over the last few years, especially as I was making the transition from chemistry to biology, she was always there to check up on me. I'd basically come in with a bunch of disorganized stuff, you know, "what am I supposed to take, what am I doing, how do I apply." Like a great caring person, she sat down with me and figured it all out. I would have been lost without her...She makes lists of things that I need to do to graduate or to move on, [she] emails me with them, and then follows up after appointments.

In the larger interview, Antonio shared that this advisor not only supported him in expected ways such as selecting coursework and discussing career goals, but she went further. When Antonio was feeling overwhelmed by the "number of things on his plate," this faculty member took time to slow down and show Antonio how to navigate various obstacles. She not only supported Antonio during their one-on-one meetings, but she also followed up with Antonio regularly, checking in on how he was doing.

\section{Summary of Holistic Mentoring Practice that Students Perceived as Positive}

Students in this study described the following mentoring practices as positive.

The "and" after each practice is to imply that students likely benefit the most when all of these practices are present:

1. Inquiring as to students' well-being in and outside of the class; and

2. Advising on coursework, careers, future opportunities; and

3. Asking students for their input, ideas, and opinions; and

4. Offering advice and ideas for students' well-being and success in their academic discipline and in their larger lives and engaging in a back and forth dialogue around these topics. 
Journal Committed to Social Change on Race and Ethnicity | 2019

All of these practices could be considered holistic mentoring practices that take the students' full experience into account. While some advisors clearly went above and beyond what might be typical mentoring practices (e.g., Michelle's mentor), many of these practices could occur during regular interactions between students and faculty.

\section{Discussion}

While prior research suggests the importance of holistic faculty-student mentoring, particularly for Students of Color in STEM disciplines (Gasman et al., 2017; Hinton et al., 2009; McCoy et al., 2015; Milner, Husband, \& Jackson, 2002), there is little research that outlines the specific mentoring practices that students might perceive as holistically supportive and positive (but see, Luedke, 2017; Packard, 2015). The findings of this study suggest specific positive practices for mentoring of underrepresented students from the perspective of Students of Color. In particular, the participants at both the HBCU and the PWI noted that when faculty mentors treated them in holistic ways, they felt supported. Participants described holistic mentoring as occurring when faculty cared for the students as whole people (see also, Crisp, 2010; Luedke, 2017; Patton \& Harper, 2003). Specifically, faculty who used holistic practices asked students about their lives, engaged students in a back-and-forth dialogue on academic and career planning, and aided students in creating broad social networks so that the students could succeed in their disciplines in the future.

Our findings are consistent with Tsui's (2007) review, finding that Students of Color in STEM fields with positive mentoring experienced increased self-efficacy, and better-defined academic goals. Participants who had positive mentoring relationships often talked to their faculty mentor about academic goals, from discussing study 
Journal Committed to Social Change on Race and Ethnicity | 2019

strategies in a specific course, to selecting undergraduate research opportunities.

These relationships contributed to the cultural capital that students acquired relevant to their coursework and future careers or graduate education in STEM fields (Bourdieu, 1979/1984). Additionally, developing the relationship with their mentor may have also contributed to students' ability to see themselves as scientists. With their mentors, students discussed course work, engaged in research outside the classroom, and planned for future careers in STEM. These experiences are important in developing an identity (habitus) as a scientist, which research suggests is important to their persistence and commitment to a career in STEM (James \& Carlson, 2012; Rodriguez \& Lehman, 2018). In their relationships, faculty became important parts of the students' social capital (Bourdieu, 1979/1984) and some participants noted that these faculty contacts did help them to achieve their academic or career goals. Prior research has maintained the importance of social capital for Students of Color in STEM careers (Callahan, Libarkin, McCallum, \& Atchison, 2015).

When faculty members de-emphasized power dynamics by getting to know students holistically (not just academically), they disrupted the status quo. Mentors took time and invested in supporting the holistic development of students and as a result, students felt they had someone to turn to as questions arose around their degree programs, engagement in undergraduate research, preparation for graduate school, and job placement in STEM fields. These faculty members' actions were critical to students' experiences and their commitment to persisting in their STEM fields.

This project has implications for faculty mentoring of Students of Color. The findings suggest that holistic mentoring is possible and it may be easier than some 
initially perceive. Holistic mentoring involves taking time to get to know students as individuals and nurturing that relationship over time (Luedke, 2017). It involves demonstrating a real interest in students, and taking their thoughts and ideas into consideration when advising and mentoring. Implementing holistic mentoring may be one way to better recruit, retain, and support Students of Color in STEM disciplines. Holistic mentoring was found to be much more prevalent at the HBCU. HBCU faculty were much more likely to take pause and engage in holistic ways with students, put clearly they took time to get to know their students and supported their development beyond the classroom. This finding is consistent with other scholarship which suggests that faculty at HBCUs are more likely to provide professional development, support, and positive mentoring in their relationships with Students of Color, than faculty at PWIs (McCoy et al., 2017). Prior scholarship has found that imbalanced power dynamics in student-faculty relationships may be exacerbated at PWIs (Azizova \& Felder, 2017) and within STEM disciplines (Baber, 2015). Disrupting the unequal power-dynamics and developing more holistic approaches to supporting students contributes positively to students' educational experiences and their socialization within their discipline. PWls can take note of the myriad practices implemented at the $\mathrm{HBCU}$, and the ways in which these holistic practices contribute to students' retention and graduation. Prior research has documented the success of HBCUs in preparing STEM graduates of color (Gasman et al., 2017; McCoy et al., 2017). Future scholarship should examine the conditions at HBCUs that contribute to the differences in faculty-student interactions, and how these conditions may disrupt disparities in access to and persistence in STEM degree programs. 
Holistic mentoring may contribute to Students' of Color perspectives (habitus) about the options that are available to them in STEM disciplines, including pursuing graduate and professional education (Bourdieu, 1979/1984). If students are not mentored to persist in STEM fields and to consider graduate education in STEM fields, then the underrepresentation of People of Color in STEM will persist. Faculty who went the "extra mile" and mentored their students holistically, demonstrating a sincere interest in them, had a greater influence on their students (mentees/protégées). These faculty had more positive impacts on students' ability to see themselves as scientists (habitus), as they were encouraged to do by fellow scientists. These are the interactions that may likely contribute to disrupting the disparities in STEM fields by supporting students as they move through their STEM degrees.

\section{Practical Implications}

Prior researchers have found that faculty do not typically receive training on approaches to mentoring students (Hall \& Burns, 2009), which leads many faculty to replicate their own mentoring experiences. Graduate programs and faculty development programs should address student advising, and holistic culturally sensitive advising in particular, if we hope to change the advising culture on many college campuses. Holistic culturally sensitive mentoring should be recognized and rewarded in the tenure and promotions process for faculty. Participants in this study experienced mentoring by faculty who invested time and resources in them far beyond basic advising. Rewarding positive mentoring practices in the tenure and promotion process highlights the necessity of this important commitment to student development. Moreover, it signals an institutional commitment to disrupting processes that have 
Journal Committed to Social Change on Race and Ethnicity | 2019

historically perpetuated inequality in educational experiences. Without rewarding faculty who engage in holistic culturally sensitive mentoring, institutions may be sending a message that these practices are not valued by the institution. Institutions should consider providing training and support for all faculty to develop strategies for holistically supporting students, particularly in PWls where holistic mentoring occurred less often.

\section{Future Research}

Given the exploratory nature of this study, there are several opportunities for additional research on holistic mentoring. First, this study is limited to two institutions in

one state; future research on holistic mentoring should extend beyond the boundaries of this case study. Second, additional research should explore how culturally sensitive mentoring (see Alvarez, Blume, Cervantes, \& Thomas, 2009; Luedke, 2017; McCoy et al., 2015; Milner, et al., 2002) contributes to holistic mentoring. More specifically, in what ways does a mentor's level of cultural competence contribute to students' holistic and developmental mentoring experiences? Is cultural competence a precursor for participating in holistic mentoring of Students of Color? Additionally, research that explores how the campus culture influences the conditions for holistic mentoring is also warranted given the finding that holistic mentoring was more prevalent at the $\mathrm{HBCU}$ than at the PWI. Finally, engaging in a quantitative exploration of holistic mentoring may "generalize" the findings throughout STEM disciplines.

\section{Conclusion}

Faculty mentoring is critical to the success of students from historically underrepresented populations, particularly Students of Color in STEM disciplines. This study's findings identified four specific ways faculty mentored Students of Color. We 
Journal Committed to Social Change on Race and Ethnicity | 2019

contend that faculty must engage in all four practices to provide holistic and positive mentoring for Students of Color in the STEM disciplines. For Students of Color, holistic faculty mentoring may lead to their acquisition of additional cultural and social capital relevant to their academic disciplines and potential career fields; and alter their perspectives (habitus) of academic and career options within STEM. 


\section{References}

Abrica, E. (2015). "Thank god l'm Mexican:" Cognitive racial reappraisal strategies among Latino engineering students (Doctoral Dissertation). Retrieved from ProQuest. (Abrica_ucla_0031D_13822)

Alvarez, A. N., Blume, A. W., Cervantes, J. M., \& Thomas, L. R. (2009). Tapping the wisdom tradition: Essential elements to mentoring students of color. Professional Psychology: Research and Practice, 40(2), 181.

Astin, A. W. (1984). Student involvement: A developmental theory for higher education. Journal of College Student Development, 25, 297-308.

Azizova, Z. T. (2016). Complexity of academic socialization of historically underrepresented doctoral students: De-privileging distinctions between macroand micro-theoretical approaches. Journal Committed to Social Change on Race and Ethnicity, 2(2) 8-19.

Azizova, Z. T., \& Felder, P. P. (2017). Understanding racial/ethnic meaning making: Narrative analysis of STE[A]M doctoral student experiences. Studies in Graduate and Postdoctoral Education, 8(2), 144-168.

Baber, L. D. (2015). Considering the interest-convergence dilemma in STEM education. The Review of Higher Education, 38(2), 251-270.

Bartlett, L., \& Vavrus, F. (2016). Rethinking case study research: A comparative approach. New York, NY: Taylor \& Francis.

Benishek, L.A., Bieschke, K. J., Park, J., \& Slattery, S. (2004). A multicultural and feminist model of mentoring. Journal of Multicultural Counseling and Development, 32, 428-442.

Bourdieu, P. (1984). Distinction: A social critique of the judgment of taste. (R. Nice, Trans.). Cambridge, MA: Harvard University Press. (Original work published 1979).

Callahan, C. N., Libarkin, J. C., McCallum, C. M., \& Atchison, C. L. (2015). Using the lens of social capital to understand diversity in the earth system sciences workforce. Journal of Geoscience Education, 63(2), 98-104.

Carlone, H. B., \& Johnson, A. (2007). Understanding the science experiences of successful women of color: Science identity as an analytic lens. Journal of Research in Science Teaching, 44, 1187-1218.

Carspecken, P. F. (1996). Critical ethnography in educational research: A theoretical and practical guide. New York, NY: Routledge.

Carter, P. L. (2003). " Black" cultural capital, status positioning, and schooling conflicts for low-income African American youth. Social Problems, 50(1), 136-155.

Cole, D., \& Griffin, K. A. (2013). Advancing the study of student-faculty interaction: A focus on diverse students and faculty. In M. Paulson (Ed.), Higher education: Handbook of theory and research (pp. 561-611). Springer Netherlands.

Crisp, G. (2010). The impact of mentoring on the success of community college students. The Review of Higher Education, 34(1), 39-60.

Crisp, G., \& Cruz, I. (2009). Mentoring college students: A critical review of the literature between 1990 and 2007. Research in Higher Education, 50, 525-545.

Crisp, G., Baker, V. L., Griffin, K. A., Lunsford, L. G., \& Pifer, M. J. (2017). Mentoring undergraduate students. ASHE Higher Education Report 43(1). San Francisco, CA: Jossey-Bass. 
Davidson, M. N., \& Foster-Johnson, L. (2001). Mentoring in the preparation of graduate researchers of color. Review of Educational Research, 71, 549-574.

Flyvbjerg, B. (2006). Five misunderstandings about case-study research. Qualitative Inquiry, 12, 219-245.

Gandara, P. (1999). Priming the pump: Strategies for increasing the achievement of underrepresented minority undergraduates. New York, NY: The College Board.

Gasman, M., Nguyen, T. H., Conrad, C. F., Lundberg, T., \& Commodore, F. (2017). Black male success in STEM: A case study of Morehouse College. Journal of Diversity in Higher Education, 10(2), 181.

Ghee, M., Keels, M., Collins, D., Neal-Spence, C., \& Baker, E. (2016). Fine-tuning summer research programs to promote underrepresented students' persistence in the STEM pathway. CBE-Life Sciences Education, 15(3), 1-11.

Gipson, J., \& Mitchell, D. (2017). How high impact practices influence academic achievement for African American college students. Journal Committed to Social Change on Race and Ethnicity, 3(2), 123-144.

Griffin, K. A., Pérez, D., Holmes, A. P., \& Mayo, C. E. (2010). Investing in the future: The importance of faculty mentoring in the development of students of color in STEM. New Directions for Institutional Research, 148, 95-103.

Hall, L., \& Burns, L. (2009). Identity development and mentoring in doctoral education. Harvard Educational Review, 79(1), 49-70.

Heppner, P. P. (2017). Creating mentoring opportunities to promote cultural competencies and social justice. The Counseling Psychologist, 45, 137-157.

Hinton, K. G., Grim, V., \& Howard-Hamilton, M. F. (2009). Our stories of mentoring and guidance in a higher education and student affairs program. In M. F. HowardHamilton, C. Morelon-Quainoo, R. Winkle-Wagner, S. D. Johnson, \& L. Santiague (Eds.), Standing on the outside looking in: Underrepresented students' experiences in advanced degree programs, (pp. 184-202). Sterling, VA: Stylus.

James, K. C., \& Carlson, K. (2012). A holistic model for supporting a diverse student body in the STEM fields. In C. P. Veenstra, F. F. Padró, \& J. A. Furst-Bowe (Eds.), Advancing the STEM agenda: Quality improvement supports STEM, (pp. 11-28). Milwaukee WI: Quality Press.

Johnson, W. B., \& Huwe, J. M. (2003). Getting mentored in graduate school. Washington DC: American Psychological Association.

Luedke, C. L. (2017). Person first, student second: Staff and administrators of color supporting Students of Color authentically in higher education. Journal of College Student Development, 58(1), 37-52.

McCoy, D. L., Luedke, C. L., \& Winkle-Wagner, R. (2017). Encouraged or "weeded out" in the STEM disciplines: Students' perspectives on faculty interactions within a predominantly White and a historically Black institution. Journal of College Student Development, 58(5), 657-673.

McCoy, D. L., Winkle-Wagner, R., \& Luedke, C. L. (2015). Colorblind mentoring?: Examining White faculty mentoring of Students of Color. The Journal of Diversity in Higher Education, 8(4), 225-242. doi:10.1037/a0038676

McGee, E. O. (2016). Devalued Black and Latino racial identities: A by-product of STEM college culture? American Educational Research Journal, 53, 1626-1662. 
McGee, E. O., \& Martin, D. B. (2011). "You would not believe what I have to go through to prove my intellectual value!" Stereotype management among academically successful Black mathematics and engineering students. American Educational Research Journal, 48, 1347-1389.

McKinney de Royston, M. M., Vakil, S., Nasir, N. I. S., Ross, K. M., Givens, J., \& Holman, A. (2017). He's more like a "brother" than a teacher: Politicized caring in a program for African American males. Teachers College Record, 119(4), 8-24.

Merriam, S. B., \& Tisdell, E. J. (2016). Qualitative research: A guide to design and implementation, ( ${ }^{\text {th }}$ ed.). San Francisco, CA: Jossey-Bass.

Milner, H. R., Husband, T., \& Jackson, M. P. (2002). Voices of persistence and selfefficacy: African American graduate students and professors who affirm them. Journal of Critical Inquiry into Curriculum and Instruction, 4, 33-39.

Neumann, A. (2009). Professing to learn: Creating tenured lives and careers in the American research university (No. 475). Baltimore, MD: Johns Hopkins University Press.

Nora, A, \& Crisp, G. (2007). Mentoring students: Conceptualizing and validating the multidimensions of a support system. Journal of College Student Retention, 9 , 337-356.

Packard, B. W. L. (2015). Successful STEM mentoring initiatives for underrepresented students: A research-based guide for faculty and administrators. Herndon, VA: Stylus.

Palmer, R. T., Maramba, D. C., \& Dancy, T. E. (2011). A qualitative investigation of factors promoting the retention and persistence of students of color in STEM. The Journal of Negro Education, 80, 491-504.

Park-Saltzman, J., Wada, K., \& Mogami, T. (2012). Culturally sensitive mentoring for Asian international students in counseling psychology. The Counseling Psychologist, 40, 895-915.

Patton, L. D., \& Harper, S. R. (2003). Mentoring relationships among African American women in graduate and professional schools. New Directions for Student Services, 2003(104), 67-78.

Pinkard, N., Erete, S., Martin, C. K., \& McKinney de Royston, M. (2017). Digital youth divas: Exploring narrative-driven curriculum to spark middle school girls' interest in computational activities. Journal of the Learning Sciences, 26, 478-490.

Rodriguez, S. L., \& Lehman, K. (2018). Developing the next generation of diverse computer scientists: The need for enhanced intersectional computing identity theory. Computer Science Education. DOI: 10.1080/08993408.2018.1457899

Salinas, C., \& Lozano, A. (2017). Mapping and recontextualizing the evolution of the term Latinx: An environmental scanning in higher education. Journal of Latinos and Education, 1-14.

Schreiner, L. A., Noel, P., Anderson, E., \& Cantwell, L. (2011). The impact of faculty and staff on high-risk college student persistence. Journal of College Student Development, 52, 321-338.

Templeton, E., Love, B., Davis, B. H., \& Davis Jr, M. (2016). Illusion of inclusion: University policies that perpetuate exclusion of students of color. Journal Committed to Social Change on Race and Ethnicity, 2(1), 99-111. 
Tillman, L. C. (2001). Mentoring African American faculty in predominantly White institutions. Research in Higher Education, 42, 295-325.

Tinto, V. (1993). Leaving college: Rethinking the causes and cures of student attrition (2nd ed.). Chicago, IL: The University of Chicago Press. (Originally published in 1987).

Torrens, O. D., Salinas, C., Floyd, D. L. (2017). Examining the value of mentoring and men of color staff members of a community college. Mentoring \& Tutoring: Partnership in Learning, 25(5), 509-527.

Tsui, L. (2007). Effective strategies to increase diversity in STEM fields: A review of the research literature. The Journal of Negro Education, 76, 555-581.

Ward, E. G., Thomas, E. E., \& Disch, W. B. (2014). Mentor service themes emergent in holistic, undergraduate peer-mentoring experience. Journal of College Student Development, 55, 563-579.

Yosso, T. J. (2005). Whose culture has capital? A critical race theory discussion of community cultural wealth. Race Ethnicity and Education, 8(1), 69-91.

Young, M. D., \& Brooks, J. S. (2008). Supporting graduate students of color in educational administration preparation programs: Faculty perspectives on best practices, possibilities, and problems. Educational Administration Quarterly, 44, 391-423. 